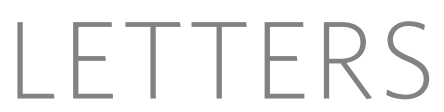

\title{
Deformation and rupture of the oceanic crust may control growth of Hawaiian volcanoes
}

\author{
Jean-Luc Got ${ }^{1}$, Vadim Monteiller ${ }^{1}$, Julien Monteux ${ }^{2}$, Riad Hassani ${ }^{1} \&$ Paul Okubo $^{3}$
}

Hawaiian volcanoes are formed by the eruption of large quantities of basaltic magma related to hot-spot activity below the Pacific Plate $^{1,2}$. Despite the apparent simplicity of the parent processemission of magma onto the oceanic crust - the resulting edifices display some topographic complexity ${ }^{3-5}$. Certain features, such as rift zones and large flank slides, are common to all Hawaiian volcanoes, indicating similarities in their genesis; however, the underlying mechanism controlling this process remains unknown ${ }^{6,7}$. Here we use seismological investigations and finiteelement mechanical modelling to show that the load exerted by large Hawaiian volcanoes can be sufficient to rupture the oceanic crust. This intense deformation, combined with the accelerated subsidence of the oceanic crust and the weakness of the volcanic edifice/oceanic crust interface, may control the surface morphology of Hawaiian volcanoes, especially the existence of their giant flank instabilities ${ }^{8-10}$. Further studies are needed to determine whether such processes occur in other active intraplate volcanoes.

To understand the morphology of Hawaiian volcanoes, we must combine geophysical information about the deep structure of the volcanoes with studies of the mechanical interactions that take place within the edifices and within the oceanic crust. In this work we first computed a three-dimensional (3D) P-wave velocity model of Mauna Loa volcano and Kilauea volcano, using data from 1,435 earthquakes that were well recorded (at least 25 stations) by the Hawaiian Volcano Observatory (HVO) network between 1988 and 1999. These events were declustered in such a way that the earthquake-station ray set optimally sampled the tomographic volume. The 44,504 high-quality $\mathrm{P}$ arrival-times were inverted using Monteiller's probabilistic algorithm ${ }^{11}$. The resulting 3D velocity model (959,077 1-km ${ }^{3}$ cubic cells) was stable and detailed, and showed most of the volcanoes' structural features (Fig. 1). Therefore, we used this model to compute double-difference locations for 1,161 highly correlated earthquakes (providing 8,444,395 crossspectral time delays of millisecond-accuracy, from 669,903 event pairs) in the south flank of Kilauea volcano recorded between 1988 and 1999 by the HVO seismic network (Fig. 2a). The quality of the velocity model ensured that the slowness vectors used in the doubledifference locations were correctly computed. Plots of time delays as a function of the angle between the slowness vector and the relative position vector for each coherent earthquake pair and each station (Supplementary Fig. 1) showed that the locations were almost perfectly coherent with the slowness vectors computed using the tomographic model. A systematic computation of the location root mean square for varying dips showed that dip is well constrained in our 3D velocity model (Supplementary Fig. 2). The double-difference location results showed earthquake locations on a subhorizontal décollement plane, and along a deeper, steeper, southward-dipping reverse fault (Fig. 2a; Supplementary Fig. 3), thus confirming some preliminary results ${ }^{12,13}$ obtained using a one-dimensional model. The inferred depth for the décollement plane $(8-9 \mathrm{~km})$ was obtained by double-difference relocation using time-delay measurements computed from widely correlated events into the $3 \mathrm{D}$ velocity model. Coherence remained greater than $80 \%$ for inter-event distances up to $1 \mathrm{~km}$, leading to a well-conditioned inversion. This provides an accuracy of better than $500 \mathrm{~m}$ for the earthquake depth calculations. The $8.5-\mathrm{km}$ depth coincides locally with the top of the oceanic crust $^{14,15}$.

Travel-time tomography was used to determine the deep structure of the volcanoes. The resulting cross-sections show roughly triangular, high-velocity cores beneath the calderas and rifts. Plots of P-wave velocities in the south flank of Kilauea along a north-south horizontal profile (Fig. 2b) showed that velocity falls substantially with distance from the rift axis. The norm of the velocity gradient is largest near the intersection of the reverse fault plane and the décollement plane. This maximum is reached for a P-wave velocity of roughly $6 \mathrm{~km} \mathrm{~s}^{-1}$, which is the limit used ${ }^{14}$ to differentiate between intrusive rocks and lava flows in Hawaiian volcanoes. Reverse faulting initiates

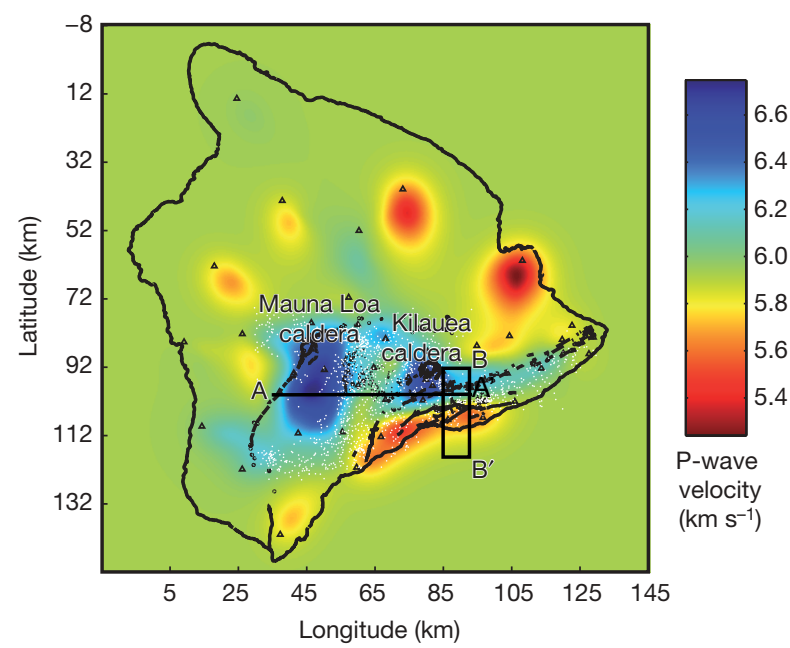

Figure 1 Map of Hawaii Island. The map shows the main topographic features, the epicentres of the earthquakes used for the tomographic model (white dots) and for the double-difference relocation (black dots), and the location of the HVO short-period seismic stations (open triangles). The solid rectangle and the solid line show the locations of the cross-sections presented respectively in Figs 2a and b, and in Fig. 4. Colour is used to represent $\mathrm{P}$-wave seismic velocities after travel-time tomographic inversion, at $6 \mathrm{~km}$ depth. The resulting model is the simplest that best fits the data (optimal a priori information: velocity parameter correlation length $\lambda=5 \mathrm{~km}$, velocity standard deviation $\sigma_{v}=1 \mathrm{~km} \mathrm{~s}^{-1}$ ). It may be compared to former P-wave velocity models ${ }^{26,27}$. 
near the core/cover boundary, at the depth of the décollement plane, and propagates through the oceanic crust.

To ascertain the conditions required for such a rupture of the oceanic crust to take place, we drew up a mechanical model of the interaction between Hawaiian-type volcanoes and oceanic crust. Geometrical boundary conditions and constitutive laws of these bodies are provided by tomographic results and by Hill and

\section{a}

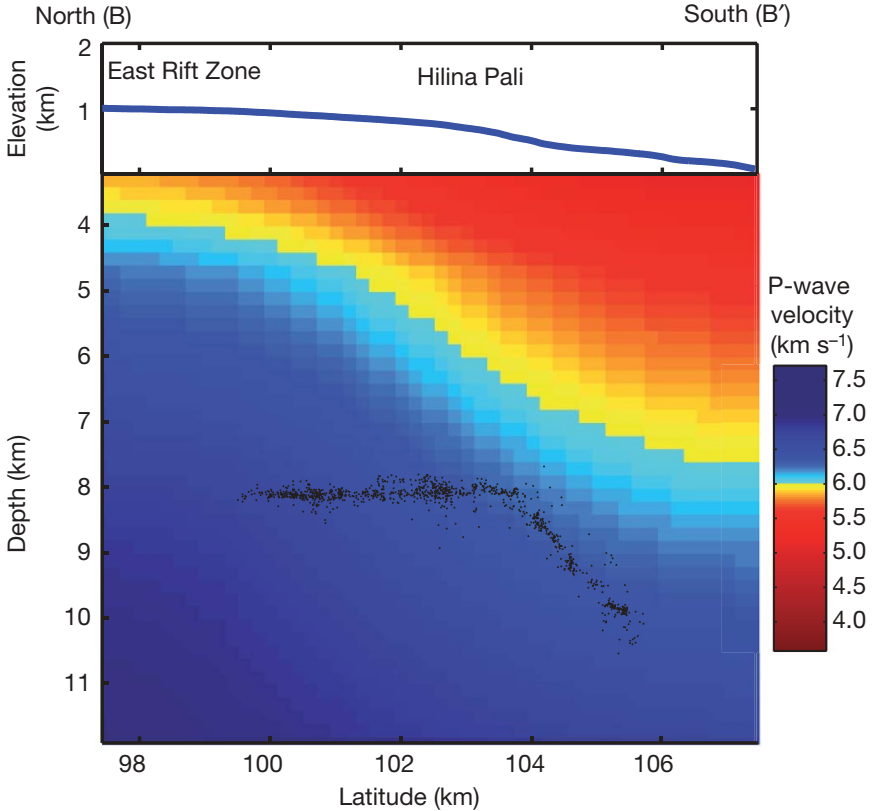

b

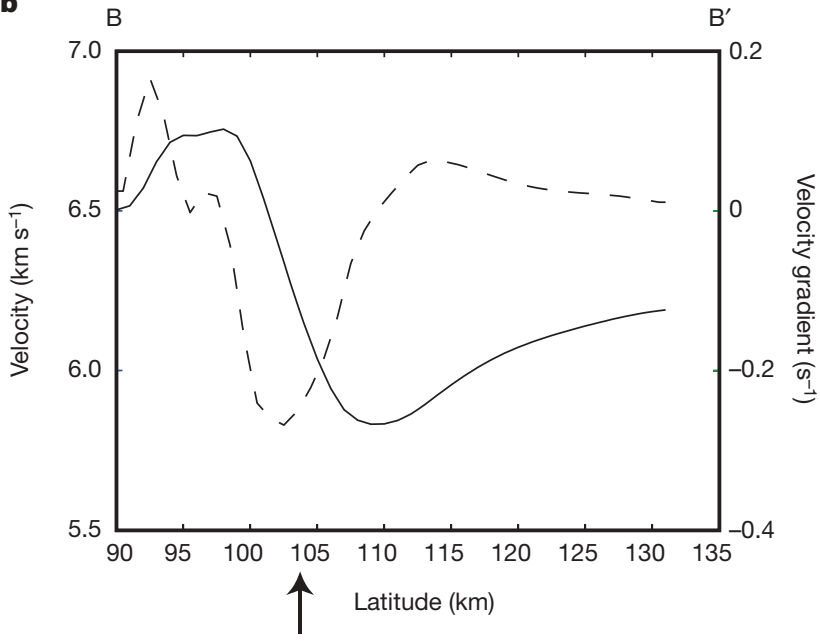

Top of reverse fault

Figure 2 | Double-difference location and tomography results.

a, North-south cross-section of the velocity model (Fig. 1) and location of relocated earthquakes on the south flank of Kilauea volcano. The colour scale highlights the velocity interval of $5.8-6.2 \mathrm{~km} \mathrm{~s}^{-1}$ that marks ${ }^{14}$ the separation between intrusive rocks (core rocks) and lava flows (cover rocks). Double-difference relocation uses this tomographic velocity model, thereby ensuring that ray parameters are correctly calculated. We carried out relocation using 1,161 correlated earthquakes (coherence $>80 \%$ ) on the south flank of Kilauea volcano recorded by the HVO network between 1988 and 1999. The average errors for the relocations were found to be $100 \mathrm{~m}$ vertically and $50 \mathrm{~m}$ horizontally. b, Velocity (solid line) and velocity gradient (dashed line) as a function of distance along a horizontal north-south profile across the south flank of Kilauea. The velocity profile is the mean, at $8.5 \mathrm{~km}$ depth, of 10 north-south contiguous profiles across the rectangular area $\mathrm{B}-\mathrm{B}^{\prime}$ indicated in Fig. 1. The arrow indicates the abscissa of the intersection of the reverse fault with the décollement plane; it shows that the reverse fault initiates in the neighbourhood of the highest velocity gradient (core/cover boundary).
Zucca's correspondence ${ }^{14}$ between local rock formations and velocities. Drilling experiments ${ }^{16}$ in and around rift zones have shown that the peripheral cover surrounding rift zones is mainly composed of altered lavas whose mechanical properties are characterized by low Young's modulus, cohesion and friction coefficient. We therefore represented the slow peripheral cover by an elastic-plastic material, and carried out various numerical experiments using an elastic or elastic-plastic material for the dense and fast cores (Fig. 3; Supplementary Figs 4-9). The oceanic crust was represented by an elasticplastic material ${ }^{17}$. Basal décollement (top of the oceanic crust) is represented by an interface with a Coulomb friction law (angle of friction $\left.\phi=10^{\circ}\right)^{4,18}$. Finite-element calculations of the deformation of this model were carried out using the ADELI code ${ }^{19}$. They showed
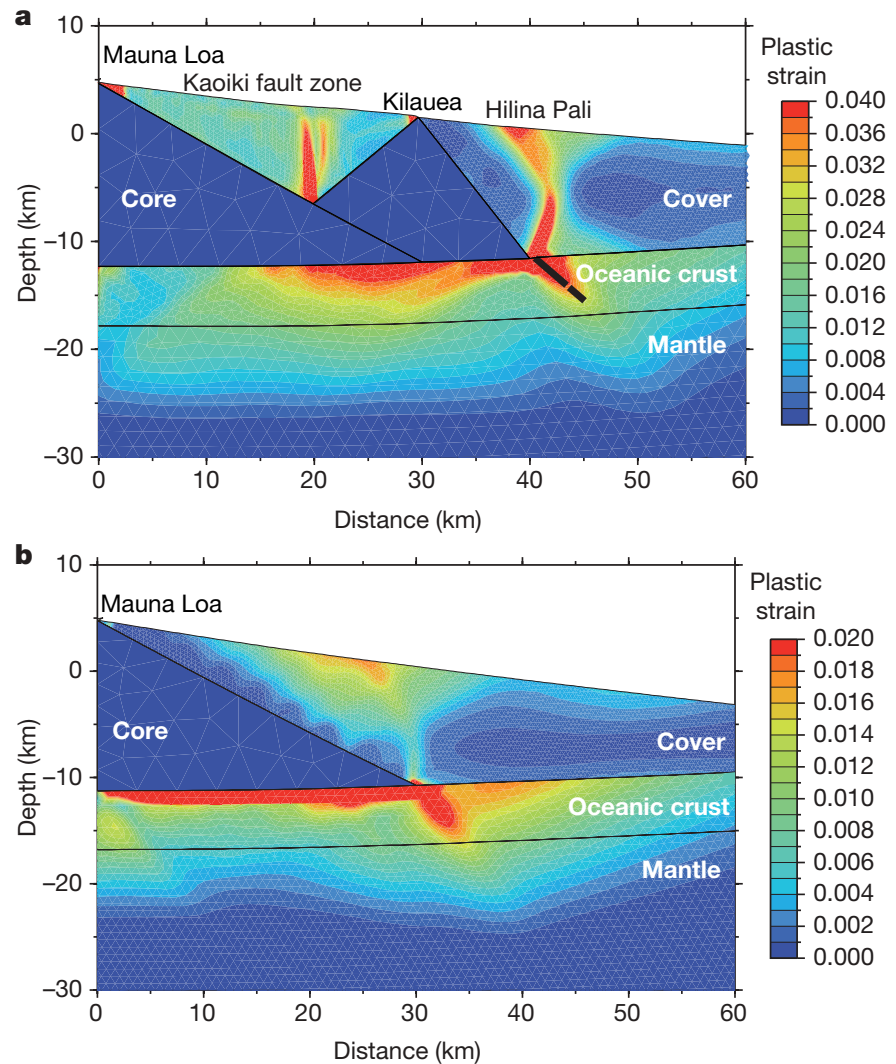

Figure 3 | Model of the mechanical interaction between the volcanic edifice and the oceanic crust. a, Mauna Loa and Kilauea volcanoes are both represented by a dense and elastic core (Young's modulus $E=100 \mathrm{GPa}$, Poisson's ratio $v=0.25$, density $\rho=2,900 \mathrm{~kg} \mathrm{~m}^{-3}$ ), and a light elastic-plastic cover $\left(E=60 \mathrm{GPa}, v=0.25\right.$, cohesion $C=1 \mathrm{MPa}$, angle of friction $\phi=15^{\circ}$, $\left.\rho=2,600 \mathrm{~kg} \mathrm{~m}^{-3}\right)$. The oceanic crust is represented by an elastic-plastic material $^{17}\left(E=100 \mathrm{GPa}, v=0.25, C=1 \mathrm{MPa}, \phi=15^{\circ}, \rho=2,900 \mathrm{~kg} \mathrm{~m}^{-3}\right)$. The décollement plane is represented by an interface with a Coulomb friction law $\left(\phi=10^{\circ}\right)^{4,18}$. The dimensions of the cores were deduced from the tomographic model. Colours are used to show the plastic deformation (norm of the deviatoric plastic strain tensor). Notice the plasticized shear zone created at the edge of the dense core. Deformation in the volcanic edifice and along the décollement plane is due to the gravitational and flexural stresses. Introducing a moderate amount of plasticity

(Supplementary Fig. 4: $C=5 \mathrm{MPa}, \phi=25^{\circ}$ ) in the cores does not notably change the computed deformations. A homogeneous elastic-plastic model for cores, covers and oceanic crust (Supplementary Fig. 5) preserves a recognizable plasticized shear zone at the edge of the Kilauea dense core. b, Model of the squeezing of the elastic-plastic oceanic crust by an isolated volcano the size of Mauna Loa. A plasticized shear zone, which cuts through the entire oceanic crust, is created at the edge of the dense core. It has a dip comparable to the reverse fault dip found by double-difference relocation (Fig. 2a). Additional horizontal displacement due to the expansion of the rift zones does not change the major features evidenced at lower strain rates (Supplementary Fig. 6). 
that, provided there is a realistic density contrast between the core and the cover, the deviatoric stress can locally attain the plasticity threshold and reverse faults can cut through the oceanic crust. Thus, the load of the volcano can cause intense plastic deformation of the oceanic crust, even though the volcano may be of limited size (for example, Kilauea) (Fig. 3a). A large enough volcano (for example, Mauna Loa) may rupture the oceanic crust completely (Fig. 3b). Petrological and volcanological features ${ }^{20,21}$ have provided further evidence for oceanic crust rupture under the load of Hawaiian volcanoes. Our model also shows that the effusive cover, both between Mauna Loa and Kilauea (Kaoiki fault zone), and on the south flank of Kilauea volcano (Hilina fault scarps), is plasticized by the squeezing action of the cores of the volcanoes (Fig. 3a; Supplementary Fig. 4).

Double-difference relocation of 732 earthquakes (Fig. 4) indicated that décollement earthquakes occur at depths of around 10 to $11 \mathrm{~km}$ under Mauna Loa and at depths of around 8 to $9 \mathrm{~km}$ under the south flank of Kilauea. The vertical uncertainty for these relocations was less than $500 \mathrm{~m}$. The difference in décollement depth is about $2 \pm 1 \mathrm{~km}$ for 10 to $15 \mathrm{~km}$ horizontally between Mauna Loa and Kilauea volcanoes. Based on the hypothesis that the décollement plane coincides with the top of the oceanic crust, the top of the oceanic crust between Kilauea and Mauna Loa slopes at an angle of $9 \pm 5^{\circ}$, whereas the average slope below the oceanic crust of the Hawaiian islands is between 1.5 and $3^{\circ}$. This has been confirmed by careful inspection of active seismic results ${ }^{14,15}$. Such local variations in flexure may be considered anomalous; they cannot be explained using homogeneous elastic models ${ }^{22}$. Elastic-plastic models (Fig. 3) also place the bases of Mauna Loa and Kilauea volcanoes at similar levels. If such a slope variation was confined to the 5- to 6-km-thick crust, it would represent an unrealistic deformation greater than $15 \%$; hence this deformation must also concern the upper mantle. Interestingly, the southwest rift zone occupies the same position with respect to Mauna Loa as the reverse fault revealed by double-difference location occupies with respect to Kilauea. These observations and the results of elastic-plastic modelling on the scale of Mauna Loa (Fig. 3b) suggest that the rift system forming Kilauea may have initiated in the local rupture of the oceanic crust caused by the loading exerted by Mauna Loa, leading to magmatic eruption, collapse of the oceanic crust below Mauna Loa (eventually accelerated by the relative displacement of the mantle plume) and further propagation of the rift as fast as the volcanic load increases. At depth, the seismicity $(\sim 30 \mathrm{~km})$ in the neighbourhood of the Mauna Loa/Kilauea volcano feeding

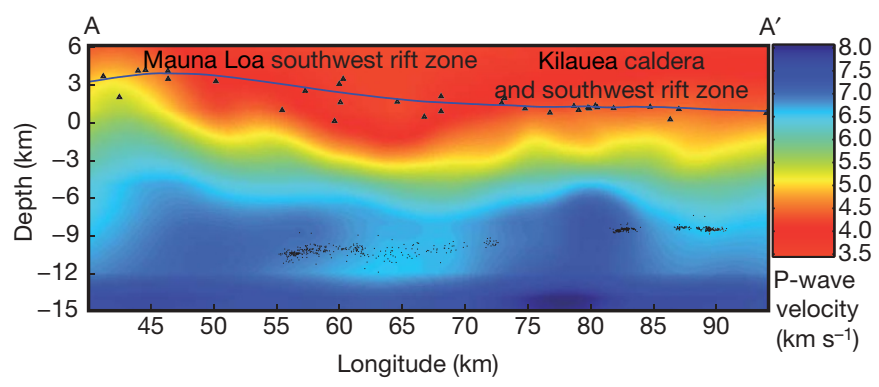

Figure 4 | East-west cross-section between Mauna Loa and the south flank of Kilauea. See earthquake locations and profile A-A', Fig. 1. The cross-section shows the tomographic model and relocated earthquakes (black dots). Resolution of the tomographic model is represented through a chequerboard test (Supplementary Fig. 9). We identified 732 relocated earthquakes along the décollement plane beneath Mauna Loa and the south flank of Kilauea by using a cross-spectral coherence criterion (similarity of the waveforms), and relocated them using cross-spectral time delays. We selected events located beneath the easternmost part of the southeast flank of Mauna Loa (longitude: 62 to $72 \mathrm{~km}$ ) for the similarity of their travel times and focal mechanisms, and relocated them using travel-time differences. Relocation results may be compared to former locations computed along similar profiles ${ }^{28,29}$ system indicates movements ${ }^{6}$ along subhorizontal planes, consistent with the flexural stresses ${ }^{7}$ induced by the volcanic load.

Geodetic measurements clearly show that Kilauea and, to a lesser extent, Mauna Loa grow horizontally ${ }^{23-25}$. Therefore, topographic variations in the top of the oceanic crust may also constrain the (horizontal) growth of Hawaiian volcanoes. It is often thought that Kilauea buttresses Mauna Loa, blocking its seaward displacement. The topography of the oceanic crust may provide a more efficient explanation. The horizontal force, $F$, required to move a non-deformable wedge of weight $P$, along a slope inclined at an angle $\theta$, and with an internal angle of friction $\phi$ is $F=P \tan (\theta+\phi)$. The apparent basal friction coefficient along the décollement plane of Kilauea volcano is thought to be very low ${ }^{4,18}$ (close to $0.1, \phi \approx 5^{\circ}$ to $\left.10^{\circ}\right)$. With such friction coefficients, slope variation appears to be a critical factor in determining the mechanical evolution of Mauna Loa and Kilauea: more than three times as much energy is required to move a body up a $10^{\circ}$ slope than along a horizontal surface. To reach an equivalent value by increasing the weight, $P$, of the wedge, the thickness of Kilauea volcano would have to be double the thickness of the southeast flank of Mauna Loa, which is contrary to the best recent estimates ${ }^{5}$.

Topographical variations in the top of the oceanic crust could also explain why the surface topographic slopes are steeper near large eruptive centres, such as Mauna Loa ${ }^{3}$. The apparent coefficient of friction increases with the slope of the oceanic crust and the edifice remains stable for higher topographic slopes, as long as it has sufficient internal strength ${ }^{4,18}$. The variations in the slope of the oceanic crust across and along the rift zones, added to the squeezing action of the central core on the plastic cover (Supplementary Fig. 6), may therefore explain the giant gravitational readjustments observed ${ }^{8-10}$.

The topography of the oceanic crust may also be responsible for (1) the blocking and relatively weak eruptive activity along the southwest rift zone, and (2) the existence of an 'aseismic' zone along the ramp, whereas the southeast flank of Mauna Loa shows some horizontal displacement ${ }^{25}$. Could this zone accumulate sufficient stress to be the source of major earthquakes, such as the great Kau (magnitude $\sim 8$ ) earthquake, today's expression of Lipman's 'piggyback' tectonics ${ }^{5}$ ?

\section{Received 12 April; accepted 12 November 2007}

1. Wilson, J. T. A possible origin of the Hawaiian Islands. Can. J. Phys. 41, 863-870 (1963).

2. Morgan, W. J. Convection plumes in the lower mantle. Nature 230, 42-43 (1971).

3. Mark, R. K. \& Moore, J. G. in Volcanism in Hawaii (eds Decker, R. W., Wright, T. L. \& Stauffer, P. H.) US Geol. Surv. Prof. Pap. 1350, 101-107 (1987).

4. Morgan, J. K. Volcanotectonic interactions between Mauna Loa and Kilauea: insights from 2-D discrete element simulations. J. Volcanol. Geotherm. Res. 150, 109-131 (2006).

5. Lipman, P. W., Sisson, T. W., Coombs, M. L., Calvert, A. \& Kimura, J.-I. Piggyback tectonics: long-term growth of Kilauea on the south flank of Mauna Loa. J. Volcanol. Geotherm. Res. 151, 73-108 (2006)

6. Wolfe, C., Okubo, P. G. \& Shearer, P. Mantle fault zone beneath Kilauea volcano, Hawaii. Science 300, 478-480 (2003).

7. Pritchard, M. E., Rubin, A. M. \& Wolfe, C. J. Do flexural stresses explain the mantle fault zone beneath Kilauea volcano? Geophys. J. Int. 168, 419-430 (2007)

8. Lipman, P. W., Normark, W. R., Moore, J. G., Wilson, J. B. \& Gutmacher, C. E. The giant submarine Alika debris slide, Mauna Loa, Hawaii. J. Geophys. Res. 93, 4279-4299 (1988).

9. Moore, J. G. et al. Prodigious submarine landslides on the Hawaiian ridge. J. Geophys. Res. 94, 17465-17484 (1989).

10. Moore, J. G., Normark, W. R. \& Holcomb, R. T. Giant Hawaiian landslides. Annu. Rev. Earth Planet. Sci. 22, 119-144 (1994).

11. Monteiller, V., Got, J.-L., Virieux, J. \& Okubo, P. G. An efficient algorithm for double-difference tomography and location in heterogeneous media, with an application to the Kilauea volcano, Hawaii. J. Geophys. Res. 110, B12306 doi:10.1029/2004JB003466 (2005).

12. Got, J.-L., Fréchet, J. \& Klein, F. W. Deep fault plane geometry inferred from multiplet relative relocation beneath the south flank of Kilauea. J. Geophys. Res. 99, 15375-15386 (1994)

13. Got, J.-L. \& Okubo, P. G. New insights into Kilauea's volcano dynamics brought by large-scale relative relocation of microearthquakes. J. Geophys. Res. 108, 2337 doi:10.1029/2002JB002060 (2003).

14. Hill, D. P. \& Zucca, J. J. in Volcanism in Hawaii (eds Decker, R. W., Wright, T. L. \& Stauffer, P. H.) US Geol. Surv. Prof. Pap. 1350, 903-917 (1987). 
15. Watts, A. B. \& ten Brink, U. S. Crustal structure, flexure and subsidence history of the Hawaiian islands. J. Geophys. Res. 94, 10473-10500 (1989).

16. Schiffman, P., Watters, R. J., Thompson, N. \& Walton, A. W. Hyaloclastites and the slope stability of Hawaiian volcanoes: insights from the Hawaiian Scientific Drilling Project's 3-km drill core. J. Volcanol. Geotherm. Res. 151, 217-228 (2006).

17. Hassani, R., Jongmans, D. \& Chéry, J. Study of plate deformation and stress in subduction processes using two-dimensional numerical models. J. Geophys. Res. 102, 17951-17965 (1997).

18. Dieterich, J. H. Growth and persistence of Hawaiian volcanic rift zones. J. Geophys. Res. 93, 4258-4270 (1988)

19. Hassani, R. \& Chéry, J. Anelasticity explains topography associated with Basin and Range normal faulting. Geology 24, 1095-1098 (1996).

20. Jackson, E. D., Shaw, H. R. \& Bargar, K. E. Calculated geochronology and stress field orientation along the Hawaiian chain. Earth Planet. Sci. Lett. 26, 145-155 (1975).

21. Davis, A. S. \& Clague, D. A. Volcaniclastic deposits from the North Arch volcanic field, Hawaii: explosive fragmentation of alkalic lava at abyssal depths. Bull. Volcanol. 68, 294-307 (2006)

22. Wessel, P. A re-examination of the flexural deformation beneath the Hawaiian islands. J. Geophys. Res. 98, 12177-12190 (1993).

23. Swanson, D. A., Duffield, W. A. \& Fiske, R. S. Displacement of the south flank of Kilauea volcano: The result of forceful intrusion of magma into the rift zones. US Geol. Surv. Prof. Pap. 963, 1-39 (1976).
24. Owen, S. et al. Rapid deformation of the south flank of Kilauea volcano, Hawai'i. Science 267, 1328-1332 (1995).

25. Miklius, A. \& Cervelli, P. Interaction between Kilauea and Mauna Loa. Nature 421, 229-230 (2003).

26. Thurber, C. H. Seismic detection of the summit magma complex of Kilauea Volcano, Hawaii. Science 223, 165-167 (1984)

27. Okubo, P., Benz, H. M. \& Chouet, B. A. Imaging the crustal magma sources beneath Mauna Loa and Kilauea volcanoes, Hawaii. Geology 25, 867-870 (1997).

28. Denlinger, R. P. \& Okubo, P. G. Structure of the mobile south flank of Kilauea Volcano, Hawaii. J. Geophys. Res. 100, 24499-24507 (1995).

29. Klein, F. W., Koyanagi, R. Y., Nakata, J. S. \& Tanigawa, W. R. in Volcanism in Hawaii (eds Decker, R. W., Wright, T. L. \& Stauffer, P. H.) US Geol. Surv. Prof. Pap. 1350, 1019-1186 (1987)

Supplementary Information is linked to the online version of the paper at www.nature.com/nature.

Acknowledgements This work was supported by grants from CNRS. (J.-L. G.) and CEA (V.M.)

Author Information Reprints and permissions information is available at www.nature.com/reprints. Correspondence and requests for materials should be addressed to J.-L.G. (e-mail: jlgot@univ-savoie.fr). 